\title{
Monoclonal Antibody-defined Immunoregulatory Cells in Multiple Sclerosis Cerebrospinal Fluid
}

\author{
Neil Cashman, Claude Martin, Jean-François Eizenbaum, Jean-Denis Degos, \\ and MARIE-ANNe BACH, Hôpital Necker, Institut National de la Santé et de la \\ Recherche Medicale, 75730 Paris, Hôpital Henri Mondor, Service de \\ Neurologie, 94000 Creteil, France
}

A B S TRACT To determine if previously reported peripheral blood suppressor cell defects are also found in the central nervous system (CNS) of patients with multiple sclerosis (MS), we studied cerebrospinal fluid (CSF) and peripheral blood lymphocytes from $40 \mathrm{MS}$ patients and 15 patients with other neurological diseases. With an indirect immunofluorescence technique using the OKT series of monoclonal antibodies (OKT4, marking helper/inducer cells, OKT5 and OKT8 marking suppressor/cytotoxic cells, and OKT3 marking all peripheral $T$ cells) we found that MS patients tested in the first 2 wk of exacerbation had invariably diminished CSF suppressor/cytotoxic cells, which was followed by an elevation of these cells in the 3rd wk of exacerbation. Repeat studies of three patients showed that perturbations of CSF suppressor/cytotoxic cells were dependent on clinical status. These observations add to the accumulating data that suggest altered immunity in the pathogenesis of MS.

\section{INTRODUCTION}

Multiple sclerosis $(\mathrm{MS})^{1}$ is a disease characterized by episodic central nervous system (CNS) demyelination, the mechanism and etiology of which are poorly understood; current hypotheses favor a primary role for altered immunity against viral and/or self-antigens (reviewed in references 1 and 2). The plethora of reports of abnormal humoral immunity in MS-including raised titers of antibodies to measles and other

Address reprint requests to Dr. Marie-Anne Bach, Département d'Immunologie, Institut Pasteur, 75724 Paris Cédex 15, France.

Received for publication 30 December 1981 and in revised form 2 April 1982.

${ }^{1}$ Abbreviations used in this paper: CNS: central nervous system; CSF: cerebrospinal fluid; MS: multiple sclerosis; OND: other neurological diseases; PB: peripheral blood. viruses (1) and antibodies to several CNS components $(2,3)$ - has been followed in recent years by reports of cellular immune abnormalities $(2,4-11)$. One of the most consistent and attractive findings relates to suppressor cells; most studies agree that circulating suppressor cell numbers (measured by membrane markers) (5, 8-11) and suppressor cell function (determined in various in vitro systems) $(4,6,7)$ are altered during the acute phases of MS. It is theorized that a loss of suppression in MS may indicate a deregulation of immune "homeostasis" in the CNS, permitting an uncontrolled immune response to self or viral antigens $(10,11)$.

One major problem with the above studies is that the peripheral blood (PB), where suppressor markers and function have been measured, may not accurately reflect the immune perturbations that accompany MS at the site of its target organ. A study of the cerebrospinal fluid (CSF), which may be considered a "sink" for humoral $(12)$ and cellular $(13,14)$ processes occuring in the CNS, might answer this question.

Recently, purified heteroantisera and monoclonal antibodies have made it possible to distinguish immunoregulatory lymphocyte subsets that had been previously defined by functional properties or by physiologically labile membrane markers (15). Disturbances of immunoregulatory cell subset composition have been reported in a variety of diseases using an indirect immunofluorescence technique with manual or automated counting of labeled cells $(16,17)$.

In this study we report a manual indirect immunofluorescence technique suitable for quantitating CSF immunoregulatory cells. Using the OK series of monoclonal antibodies, we have been able to quantitate total $\mathbf{T}$ cells $($ OKT $3+$ ), helper/inducer (OKT4 + ), and suppressor/cytotoxic cells (OKT5+ and OKT8+) in the CSF and PB of patients with MS and other neurological diseases (OND). 


\section{METHODS}

Patients. 45 paired samples of CSF and PB from 40 patients (mean age 39.8) with definite MS as defined by Schulmacher criteria (18) were studied from the Henri Mondor Hospital in the Paris area. One patient received corticosteroids in the month before testing; no other patients received immunoactive drugs during this period. Patients were assigned to one of three groups: exacerbations (31 samples from 26 patients with new neurologic signs up to 6 mo before testing), remission (9 patients with no new neurologic signs for at least $6 \mathrm{mo}$ ), and chronic progression (5 patients with gradual neurologic worsening without remission). Patients with a progressive form who suffered a rapid worsening of neurologic status superimposed upon their chronic course were included in the exacerbation group ( 2 patients). In addition, for the purposes of analysis, exacerbating patients were subdivided into three subgroups: a group between 2 wk before and $2 \mathrm{wk}$ after the onset of neurologic worsening (group I, 11 samples), a group in the 3rd wk of exacerbation (group II, 8 samples), and a group from 4 wk to 6 mo after the onset of exacerbation (group III, 12 samples).

15 samples from 15 patients with OND (mean age 48.4) undergoing lumbar puncture for diagnostic purposes, were obtained from the neuroradiology department and general neurology wards of Henri Mondor Hospital.

Monoclonal antibodies. The monoclonal antibodies used in this study for mononuclear cell phenotypic analysis (OKT3, OKT4, OKT5, and OKT8) $(15,17,20)$ were the generous gift of P. Kung and G. Goldstein (Ortho Pharmaceuticals, Raritan, NJ). OKT3, the pan-T marker, reacts with $100 \%$ of peripheral T cells. OKT4, marking the helper/ inducer subset, reacts with $\sim 60 \%$ of peripheral $T$ cells. OKT5 and OKT8 react with the same membrane structure present on suppressor/cytotoxic T cells, but OKT8 detects $\sim 10 \%$ more cells than OKT5, which reacts with $20 \%$ of peripheral $\mathbf{T}$ cells.

Isolation and phenotyping of CSF mononuclear cells. 15-20 ml of CSF were obtained by atraumatic lumbar puncture and examined in our laboratory not more than $5 \mathrm{~h}$ later. Fetal calf serum (Flow Laboratories, Paris), to a final concentration of $30 \%$, was added to CSF that was centrifuged at $400 \mathrm{~g}$ for $10 \mathrm{~min}$ in conical bottom $30 \times 100-\mathrm{mm}$ tubes. Cells thus obtained, almost all mononuclear cells with rare polymorphs, were counted in a hemocytometer and apportioned in $9 \times 42-\mathrm{mm}$ microhemolysis tubes, 3,000-5,000/ determination in a volume of $45 \mu \mathrm{l} .5 \mu \mathrm{l}$ of the appropriate dilution of monoclonal antibody was added to the tubes, which were incubated on ice for $30 \mathrm{~min}$. After incubation, the cells were washed two times with $1 \mathrm{ml}$ of Hanks' balanced salt solution (Eurobio, Paris) with $5 \%$ fetal calf serum and $0.02 \%$ sodium azide and then incubated for a second time with $5 \mu$ l of the appropriate dilution of fluoresceinconjugated goat anti-mouse IgG serum (Miles Laboratories, Inc., Elkhart, IN), absorbed on a human IgG immunoadsorbent to eliminate cross-reacting antibodies, purified on a mouse IgG immunoadsorbent, and conjugated to fluorescein isothiocyanate. After a second incubation of $30 \mathrm{~min}$ on ice, the cells were washed again two times with the above solution and finally concentrated to $\sim 10-20 \mu \mathrm{l}$. This suspension was placed on a slide between two strips of double-stick tape to reduce dispersion of the drop by the cover slip, and was observed for fluorescence in a Leitz orthoplan fluorescence microscope (E. Leitz, Inc., Rockleigh, NJ). Usually between 100 and 300 cells were counted. Less than $15 \%$ of subjects tested had one or more determinations that did not meet these criteria. No determination was included if $<50$ cells could be counted. Negative controls, including OKT6 that detects immature thymocytes, (20) labeled $<1 \%$ of cells.

TABLE I

CSF Lymphocyte Subsets

\begin{tabular}{|c|c|c|c|c|c|c|}
\hline & \multirow[b]{2}{*}{ Remission } & \multicolumn{3}{|c|}{ Exacerbation } & \multirow{2}{*}{$\begin{array}{l}\text { Chronic } \\
\text { progressive }\end{array}$} & \multirow[b]{2}{*}{ OND } \\
\hline & & Group I & Group II & Group III & & \\
\hline Lymphocytes $/ \mathrm{mm}^{3}$ & $\begin{array}{c}5.7 \pm 1.9 \\
9\end{array}$ & $\begin{array}{c}9.0 \pm 2.6 \\
11\end{array}$ & $\begin{array}{c}3.8 \pm 1.3 \\
8\end{array}$ & $\begin{array}{c}3.8 \pm 0.6 \\
12\end{array}$ & $\begin{array}{c}3.3 \pm 1.8 \\
5\end{array}$ & $\begin{array}{c}9.0 \pm 7.0 \\
15\end{array}$ \\
\hline OKT3+ & $\begin{array}{c}88.2 \pm 2.4 \\
9\end{array}$ & $\begin{array}{c}87.4 \pm 1.8 \\
9\end{array}$ & $\begin{array}{c}90.1 \pm 1.7 \\
8\end{array}$ & $\begin{array}{c}87.3 \pm 1.5 \\
10\end{array}$ & $\begin{array}{c}88.5 \pm 0.5 \\
2\end{array}$ & $\begin{array}{c}88.5 \pm 1.5 \\
10\end{array}$ \\
\hline OKT4+ & $\begin{array}{c}66.6 \pm 2.6 \\
9\end{array}$ & $\begin{array}{c}69.1 \pm 2.5 \\
10\end{array}$ & $\begin{array}{c}64.1 \pm 2.8 \\
8\end{array}$ & $\begin{array}{c}67.1 \pm 2.6 \\
11\end{array}$ & $\begin{array}{c}64.7 \pm 2.4 \\
3\end{array}$ & $\begin{array}{c}64.1 \pm 3.2 \\
10\end{array}$ \\
\hline OKT5+ & $\begin{array}{c}21.0 \pm 5.0 \\
3\end{array}$ & $\begin{array}{c}13.3 \pm 1.0 \\
9\end{array}$ & $\begin{array}{c}22.0 \pm 5.0 \\
5\end{array}$ & $\begin{array}{c}17.4 \pm 2.0 \\
9\end{array}$ & $\begin{array}{r}25 \\
1\end{array}$ & $\begin{array}{c}26.5 \pm 6.4 \\
4\end{array}$ \\
\hline OKT8+ & $\begin{array}{c}23.2 \pm 2.4 \\
9\end{array}$ & $\begin{array}{c}14.5 \pm 0.5 \\
11\end{array}$ & $\begin{array}{c}31.4 \pm 3.9 \\
8\end{array}$ & $\begin{array}{c}19.8 \pm 1.2 \\
12\end{array}$ & $\begin{array}{c}21.0 \pm 1.1 \\
5\end{array}$ & $\begin{array}{c}28.4 \pm 2.8 \\
11\end{array}$ \\
\hline OKT4+/OKT8+ & $\begin{array}{c}3.17 \pm 0.39 \\
9\end{array}$ & $\begin{array}{c}4.80 \pm 1.28 \\
10\end{array}$ & $\begin{array}{c}2.42 \pm 0.46 \\
8\end{array}$ & $\begin{array}{c}3.63 \pm 0.52 \\
11\end{array}$ & $3.33 \pm 0.30$ & $\begin{array}{c}2.59 \pm 0.32 \\
10\end{array}$ \\
\hline
\end{tabular}

OKT3+ (T) cells, OKT4+ (helper/inducer T cells), OKT5+ and OKT8+ (suppressor/cytotoxic T cells) are expressed in percentages of labeled cells \pm SEM. The OKT4+/OKT8+ index, a ratio between the percentages of OKT4+ and OKT8+ cells, is a global expression of immunoregulatory status. The number of patients tested for each parameter is listed below the mean for each group. Remission: no new neurologic signs for at least 6 mo. Group I: from 2 wk before to 2 wk after an acute exacerbation. Group II: 3rd wk of exacerbation. Group III: from 3 wk to 6 mo after onset of exacerbation. Chronic progressive: unrelenting neurological deterioration. 
PB mononuclear cell isolation and phenotyping. 10-15 $\mathrm{ml}$ of blood was obtained from patients within an hour of lumbar puncture. PB mononuclear cells were isolated and phenotyped as already described $(11,16)$.

Calculations. When possible, a OKT4+/OKT8+ index was computed from the OKT4+ and OKT8+ percentages. A helper/suppressor cell ratio is thought to diminish the influence of nonlymphoid contaminating cells on the absolute percentage of labeled cells $(10,11)$. Data were analyzed with Student's two-tailed $t$ test.

\section{RESULTS}

CSF $T$ cell subsets in OND and MS (Table I, Fig. 1A). We studied 15 OND patients with a variety of inflammatory and noninflammatory diseases. Two patients (neurosyphilis, CNS sarcoidosis) has CSF lymphocyte counts $>5$ cells $/ \mathrm{mm}^{3}$. OKT3+ cells ranged from 83\% (sciatica) to $96 \%$ (CNS sarcoidosis). Immunoregulatory cell subset composition ranged widely, as indicated by the percentages of OKT4+, OKT $5+$, OKT $8+$ cells, and the OKT4+/OKT8+ index. Interestingly, there was no correlation between any immunoregulatory cell percentage and the CSF lymphocyte count in OND and MS patients, indicating that immunoregulatory subset composition is probably independent of the number of cells that reach the CSF from the parenchyma.

MS remission patients had a T-cell subset pattern that was not significantly different from that of the OND group. A clear pattern of CSF lymphocyte subset distribution was seen when patients with exacerbating MS were divided into three groups according to their proximity in time to exacerbation: group I from $2 \mathrm{wk}$ before to $2 \mathrm{wk}$ after the onset of exacerbation, group II in their 3rd wk of exacerbation, and group III from the 4th wk to $6 \mathrm{mo}$ after the onset of exacerbation. Exacerbation is dated from the patient's reported date of onset.

All group I exacerbation patients had CSF OKT8+ cell percentages $<20 \%$, which was a significant depression compared with OND and remission patients $(P$ $<0.001$ for both groups). In addition OKT5+ cells were significantly depressed when compared with OND and remission patients $(P<0.02$ and $<0.05$, respectively), and the OKT4+/OKT8+ index was significantly elevated when compared with OND and remission patients $(P<0.001$ and $<0.01$, respectively).

An unexpected but highly significant finding was made when patients in their 3rd wk of exacerbation were grouped for analysis (group II). The majority of these patients had $>30 \%$ OKT $8+$ cells in the CSF and two patients exceeded $40 \%$. The difference between this group and group I patients was significant for OKT8+ cells $(P<0.001)$, OKT5 + cells $(P<0.05)$, and the OKT4+/OKT8+ index $(P<0.001)$. The mean OKT8+ cell percentage in group II patients was higher than in OND, but the difference was not statistically significant. The elevation in the percentage of OKT8+ cells cannot
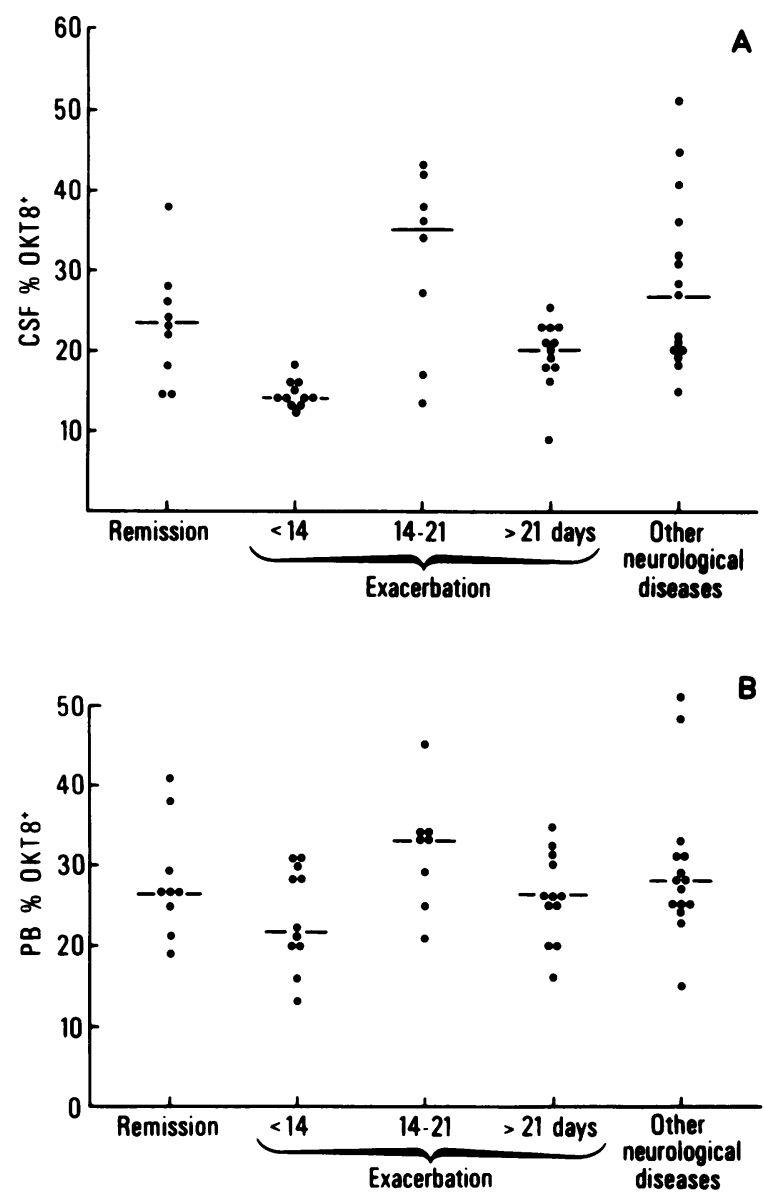

Figure 1 CSF (A) and PB (B) percentages of suppressor/ cytotoxic OKT8+ cells in MS and OND patients. Exacerbation patients are classified according to the delay between clinical onset and testing. Horizontal bars represent median values.

be explained simply by the decrease in the CSF lymphocyte count between group I and group II patients (possible preferential death of OKT4+ cells ?) because the decrease is not statistically significant.

After the 3rd wk of exacerbation there was a heterogeneous group of patients with varying clinical states (group III). The mean OKT8+ cell percentage for group III was lower than OND $(P<0.02)$, higher than group I patients $(P<0.001)$, and lower than group II patients $(P<0.001)$. This pattern was not reflected in the OKT5+ cell percentage and the OKT4+/OKT8+ index, but trends were noted $(P$ $<0.1)$.

Chronic progressive patients were not significantly different from OND or remission patients in any cell percentage, perhaps because of the small sample tested in this study. 
TABLE II

PB Lymphocyte Subsets

\begin{tabular}{|c|c|c|c|c|c|c|}
\hline & \multirow[b]{2}{*}{ Remission } & \multicolumn{3}{|c|}{ Exacerbation } & \multirow{2}{*}{$\begin{array}{c}\text { Chronic } \\
\text { progressive }\end{array}$} & \multirow[b]{2}{*}{ OND } \\
\hline & & Group I & Group II & Group III & & \\
\hline OKT3+ & $\begin{array}{c}80.6 \pm 4.0 \\
9\end{array}$ & $\begin{array}{c}72.7 \pm 2.2 \\
11\end{array}$ & $\begin{array}{c}81.8 \pm 2.3 \\
8\end{array}$ & $\begin{array}{c}69.8 \pm 3.2 \\
12\end{array}$ & $\begin{array}{c}73.2 \pm 2.4 \\
5\end{array}$ & $\begin{array}{c}80.1 \pm 1.7 \\
15\end{array}$ \\
\hline OKT4+ & $\begin{array}{c}56.1 \pm 3.9 \\
9\end{array}$ & $\begin{array}{c}51.6 \pm 2.4 \\
11\end{array}$ & $\begin{array}{c}53.6 \pm 3.4 \\
8\end{array}$ & $\begin{array}{c}43.2 \pm 2.1 \\
12\end{array}$ & $\begin{array}{c}52.2 \pm 2.8 \\
5\end{array}$ & $\begin{array}{c}53.7 \pm 1.9 \\
15\end{array}$ \\
\hline OKT5+ & $\begin{array}{c}17.4 \pm 2.3 \\
5\end{array}$ & $\begin{array}{c}19.8 \pm 1.0 \\
12\end{array}$ & $\begin{array}{c}27.0 \pm 2.3 \\
8\end{array}$ & $\begin{array}{c}20.4 \pm 1.0 \\
9\end{array}$ & $\begin{array}{c}19.0 \pm 2.1 \\
5\end{array}$ & $\begin{array}{c}22.2 \pm 1.5 \\
13\end{array}$ \\
\hline OKT8+ & $\begin{array}{c}28.3 \pm 2.4 \\
9\end{array}$ & $\begin{array}{c}23.6 \pm 1.9 \\
11\end{array}$ & $\begin{array}{c}31.8 \pm 2.5 \\
8\end{array}$ & $\begin{array}{c}26.2 \pm 1.6 \\
12\end{array}$ & $\begin{array}{c}22.0 \pm 2.3 \\
5\end{array}$ & $\begin{array}{c}29.5 \pm 2.4 \\
15\end{array}$ \\
\hline OKT4+/OKT8+ index & $\begin{array}{c}2.09 \pm 0.22 \\
9\end{array}$ & $\begin{array}{c}2.39 \pm 0.28 \\
11\end{array}$ & $\begin{array}{c}1.79 \pm 0.21 \\
8\end{array}$ & $\begin{array}{c}1.72 \pm 0.12 \\
12\end{array}$ & $\begin{array}{c}2.50 \pm 0.36 \\
5\end{array}$ & $\begin{array}{c}2.00 \pm 0.21 \\
15\end{array}$ \\
\hline
\end{tabular}

OKT3+ (T) cells, OKT4+ (helper/inducer T cells), OKT5+ and OKT8+ (suppressor/cytotoxic T cells) are expressed in percentages of labeled cells \pm SEM. The OKT4+/OKT8+ index, a ratio between the percentages of OKT4+ and OKT8+ cells, is a global expression of immunoregulatory status. The number of patients tested for each parameter is listed below the mean for each group. Remission: no new neurologic signs for at least $6 \mathrm{mo}$. Group I: from $2 \mathrm{wk}$ before to $2 \mathrm{wk}$ after an acute exacerbation. Group II: 3rd wk of exacerbation. Group III: from 3 wk to 6 mo after onset of exacerbation. Chronic progressive: unrelenting neurological deterioration.

$P B T$ cell subsets in OND and MS (Table II, Fig. $1 B)$. PB values only partly reflected immunoregulatory cell subset perturbations in the CSF. When PB data were arranged in the three groups described above, there were depressions in OKT3+, OKT4+, OKT5+, and OKT8+ cells, and an elevation of the OKT4+/OKT8+ index in group I patients compared with OND. However, none of these changes reached statistical significance, due to a significant proportion of patients (5 out of 11) whose T cell subset composition was normal.
Patients tested more than once (Table III). Two OND patients were tested two times in the course of their diseases at least 1 mo apart (second determinations are not included in the OND data). A patient with CNS sarcoidosis and a patient with neurosyphilis showed $<8 \%$ fluctuation of OKT markers, despite a depression of CSF lymphocytes with therapy in both cases.

In contrast, when three patients with MS were tested more than once, acute exacerbation was associated with increased OKT3+ cells and depressed OKT8+

TABLE III

CSF Immunoregulatory Cell Data for Three MS Patients Tested More Than Once

\begin{tabular}{|c|c|c|c|c|c|c|c|c|}
\hline Patient & Date & $\begin{array}{l}\text { Exacerbation } \\
\text { phase }\end{array}$ & $\begin{array}{c}\text { CSF } \\
\text { lymphocytes } \\
\text { cells }\end{array}$ & OKT3+ & OKT4+ & OKT5+ & OKT8+ & $\begin{array}{c}\text { OKT4+/OKT8+ } \\
\text { index }\end{array}$ \\
\hline & & & $\mathrm{mm}^{\mathrm{s}}$ & & & & & \\
\hline \multirow[t]{3}{*}{1} & $11 / 19 / 80$ & II & 3 & 93 & 68 & 12 & 14 & 4.86 \\
\hline & $12 / 4 / 80$ & III & 4 & 84 & 71 & 19 & 21 & 3.38 \\
\hline & $1 / 6 / 81$ & III & 3 & 84 & 55 & 16 & 23 & 2.39 \\
\hline \multirow[t]{2}{*}{2} & $12 / 9 / 80$ & I & 9 & 84 & 66 & 16 & 16 & 4.13 \\
\hline & $1 / 5 / 81$ & III & 7 & 80 & 59 & 13 & 23 & 2.57 \\
\hline \multirow[t]{3}{*}{3} & $10 / 21 / 80$ & $\mathbf{R}$ & 2 & 76 & 50 & 31 & 38 & 1.32 \\
\hline & & I & 8 & 87 & 75 & 16 & 14 & 5.36 \\
\hline & & I & 33 & 89 & 68 & 16 & 16 & 4.25 \\
\hline
\end{tabular}

R, remission; exacerbation phase I: from 2 wk before to 2 wk after an acute exacerbation; phase II: 3rd wk of exacerbation; phase III: from $3 \mathrm{wk}$ to 6 mo after onset of exacerbation. 
cells in the CSF. OKT5+ cells were also depressed. The elevation of OKT4+ cells appears to be a poor indicator of exacerbation in these patients, but the OKT4+/OKT8+ index appears to be a good indicator. In these three patients, there was no reflection of disease activity in the PB.

\section{DISCUSSION}

We report in this study a practical method for determining mononuclear cell subset composition in the CSF, and also report immunoregulatory cell perturbations in MS CSF. We have found that the mean CSF $T$ lymphocyte percentage, as defined by the monoclonal antibody OKT3 is $\sim 90 \%$ in MS patients and in other patients with a variety of $O N D$, which is a higher percentage than in $\mathrm{PB}$, as already noted by others using a sheep erythocytes rosette assay to quantitate $T$ lymphocytes (21-23).

We observed a clear immunoregulatory cell pattern is the CSF of exacerbating MS patients when they were grouped according to their proximity in time to the onset of exacerbation, which was best expressed in OKT8+ cell percentages. In the first $2 \mathrm{wk}$, there was a significantly depressed OKT8+ cell percentage (associated with pleocytosis and an increased percentage of immunoglobulin-bearing cells) followed by a "rebound" of OKT8+ cells in the 3rd wk, and finally a CSF lymphocyte subset composition approaching that of remission patients after $3 \mathrm{wk}$ of exacerbation. In the $\mathrm{PB}$, a OKT8+ and OKT5+ cell depression, and an OKT4+/OKT8+ index elevation, were noted in the first 2 wk of exacerbation, followed by an elevation of OKT8+ and OKT5+ cells and a depression of the OKT4+/OKT8+ index, thereafter. Unlike the CSF, the PB findings did not reach statistical significance in our sample, since around half the patients showed normal T-cell subset composition at the time of study. The small size of the present sample of patients likely explains this apparent discrepancy with previous findings of ours and of other workers, who have found depression of functional suppression in the PB of acutely exacerbating MS patients $(4,6)$ and depressions of suppressor cell markers, such as OKT5+ cells (10), OKT8+ cells (11), and T expressing an Fc receptor for IgG (8). Other studies of immunoregulatory cells in MS have reported increased suppressor function $(6,7)$ and suppressor markers $(5,9)$ of patients tested late in exacerbation or in recovery from an exacerbation. This finding is also supported by our data.

The initial depression of OKT8+ cells in the CSF and $\mathrm{PB}$ during exacerbation could reflect a depression in suppressor activity in the CNS, leading to an increased immune response to certain antigens, as observed in a variety of autoimmune diseases (16). Sim- ilarly, the elevation of OKT8+ cells observed in some patients in the 3rd wk of exacerbation may indicate a rebound of suppressor cells entering the CNS, or proliferation from clones already in the CNS. This may have the effect of restoring immunoregulatory equilibrium between suppressor and helper cells and, thus, down regulating the immune response in the CNS. However, it should be stressed that the monoclonal antibodies OKT8 and OKT5 mark both suppressor and cytotoxic T cells $(20)$. It is not known if OKT8+ cells can be separated into two functional subsets or if the same cell mediates both $\mathrm{T}$-cell suppression and $\mathrm{T}$-cell cytotoxicity. Thus, the OKT8+ cell peak may represent a migration or proliferation of cytotoxic $T$ cells that are marshalled to respond to a CNS pathogen. It is interesting to note that an increase in OKT8+ cell has also been reported in several viral infections (15).

In conclusion, our data indicate immunoregulatory cell perturbations in the CSF of patients with MS that are not always reflected in the PB. A highly significant depression of suppressor/cytotoxic cells was present without exception in MS patients with acute exacerbation who were tested within 2 wk before or after the onset of exacerbation. In addition, we report a peak of CSF OKT8+ cells occurring in the 3rd wk of exacerbation that may be associated with amelioration. These data suggest that immune mechanisms are involved in the production of the MS plaque, and, further, the hope that specific immunomodulatory treatments may soon be developed to alter the course of MS.

\section{ACKNOWLEDGMENTS}

We would like to acknowledge the support and encouragement of Mr. and Mrs. Yves Suquet in the course of this project.

Financial support for this work was provided by Association pour la Recherche sur la Sclérose en Plaques and the Philippe Foundation.

\section{REFERENCES}

1. Cook, S. D., and P. C. Dowling. 1980. Multiple sclerosis and viruses: an overview. Neurology. 30: 80-91.

2. Lisak, R. P. 1980. Multiple sclerosis: evidence for immunopathogenesis. Neurology. 30: 99-105.

3. Seil, F. J. 1977. Tissue culture studies of demyelinating disease: a critical review. Ann. Neurol. 2: 345-355.

4. Arnason, B. G. W., and J. Antel. 1978. Suppressor cell function in multiple sclerosis. Ann. Immunol. (Paris). 129 C: $159-170$.

5. Santoli, D., L. Moretta, R. Lisak, D. Gilden, and H. Koprowski. 1978. Imbalances in $\mathrm{T}$-cell subpopulations in multiple sclerosis patients. J. Immunol. 4: 1369-1371.

6. Antel, J. P., B. G. W. Arnason, and M. E. Medof. 1979. Suppressor cell function in multiple sclerosis: correlation with clinical disease activity. Ann. Neurol. 5: 338-342.

7. Gonzalez, R. L., P. C. Dav, and L. E. Spitler. 1979. Altered regulation of mitogen responsiveness by sup- 
pressor cells in multiple sclerosis. Clin. Exp. Immunol. 36: 78-84.

8. Huddlestone, J. R., and M. B. A. Oldstone. 1979. T. suppressor $\left(T_{g}\right)$ lymphocytes fluctuate in parallel with changes in the clinical course of patients with multiple sclerosis. J. Immunol. 123: 1615-1618.

9. Merril, J. E., G. Biberfeld, S. Landin, A. Siden, and E. Norrby. 1980. Identification of three FcR-positive T-cell subsets $(\mathrm{T} \gamma, \mathrm{T} \mu$, and $\mathrm{T} \mu \gamma)$ in the cerebrospinal fluid of multiple sclerosis patients. Clin. Exp. Immunol. 42: 345354.

10. Reinherz, E. L., H. L. Weiner, S. L. Hauser, J. A. Cohen, J. A. Distaso, and S. F. Schlossman. 1980. Loss of suppressor $\mathrm{T}$ cells in active multiple sclerosis: analysis with monoclonal antibodies. N. Engl. J. Med. 303: 125-129.

11. Bach, M. A., F. Phan-Dinh-Tuy, E. Tournier, L. Chatenoud, J. F. Bach, C. Martin, and J. D. Degos. 1980. Deficit of suppressor $\mathrm{T}$ cells in active multiple sclerosis. Lancet. II: 1221-1223.

12. Griffin, D. E. 1981. Immunoglobulins in the cerebrospinal fluid: changes during acute viral encephalitis in mice. J. Immunol. 126: 27-31.

13. Doherty, P. C. 1973. Quantitative studies of the inflammatory process in fatal viral meningoencephalitis. Am. J. Pathol. 73: 607-621.

14. Zinkernagel, R. M., and P. C. Doherty. 1973. Cytotoxic thymus-derived lymphocytes in cerebrospinal fluid of mice with lymphocytic choriomeningitis. J. Exp. Med. 138: 1266-1269.

15. Editorial. 1980. Identifying $\mathrm{T}$ cells in man. Lancet. II: 781-782.

16. Bach, M. A., and J. F. Bach. 1981. The use of monoclonal
anti-T cell antibodies to study $T$ cell imbalances in human diseases. Clin. Exp. Immunol. 45: 449-456.

17. Reinherz, E. L., and S. F. Schlossman. 1980. Current concepts in immunology: regulation of the immune response-inducer and suppressor $\mathrm{T}$ lymphocyte subsets in human beings. N. Engl. J. Med. 303: 370-383.

18. Schumacher, G. A., G. Beebe, R. F. Kibler, L. T. Kurland, J. F. Kurtzke, F. McDowell, B. Nagler, W. A. Sibley, W. W. Tourtelotte, and T. L. Willmon. 1965. Problems of experimental trials of therapy in multiple sclerosis: report by the panel on the evaluation of experimental trials of therapy in multiple sclerosis. Ann. N. Y. Acad. Sci. 122: 552-568.

19. Reinherz, E. L., P. C. Kung, G. Goldstein, and S. F. Schlossman. 1979. A monoclonal antibody with selective reactivity with functionally mature human thymocytes and all peripheral human $\mathrm{T}$ cells. J. Immunol. 123: 1312-1317.

20. Reinherz, E. L., P. C. Kung, G. Goldstein, R. H. Levey, and S. F. Schlossman. 1980. Discrete stages of human intrathymic differentiation: analysis of normal thymocytes and leukemic lymphoblasts of T cell lineage. Proc. Natl. Acad. Sci. U. S. A. 77: 1588-1592.

21. Naess, A. 1976. Demonstration of $T$ lymphocytes in cerebrospinal fluid. Scand J. Immunol. 5: 165-168.

22. Han-Hansen, S., A. Fryden, and B. Link. 1978. B and $\mathrm{T}$ lymphocytes in cerebrospinal fluid and blood in multiple sclerosis, optic neuritis, and mumps meningitis. Acta Neurol. Scand. 58: 93-103.

23. Manconi, P. E., D. Zaccheo, O. Bugiani, M. F. Fadda, V. Griffoni, G. Mantovani, G. S. Del Giacco, and S. Tognella. 1976. $T$ and $B$ lymphocytes in normal cerebrospinal fluid. N. Engl. J. Med. 294: 49. 